\title{
Diterpenoid B derived from Plectranthus excisus inhibits the melanoma cell cycle in the B16 melanoma cell line
}

\author{
YA-NAN LIU $^{1 *}$, JUN-LIAN GU ${ }^{1 *}$, MENG-SHI MA ${ }^{1}$, HUA GUO $^{1}$, \\ LONG LIU $^{2}$, LI-RONG GUO ${ }^{1}$, YUE WANG ${ }^{1}$ and YANG LI ${ }^{1}$ \\ ${ }^{1}$ Department of Pathophysiology, Key Laboratory of Pathobiology, Ministry of Education, College of Basic Medical Sciences, \\ Jilin University, Changchun, Jilin 130021; ${ }^{2}$ Department of Cardiovascular Medicine, China-Japan Union Hospital, \\ Jilin University, Changchun, Jilin 130033, P.R. China
}

Received August 25, 2014; Accepted May 8, 2015

DOI: $10.3892 / \mathrm{mmr} .2015 .3986$

\begin{abstract}
Plectranthus excisus is widely distributed throughout northeast China. Its active ingredient, diterpenoids, exhibits significant antitumor effects. The present study examined the antitumor effects of diterpenoid B (DB), derived from Plectranthus excisus, and demonstrated that DB inhibited the proliferation of tumor cells by inhibiting the cell cycle. Reverse transcription-quantitative polymerase chain reaction and western blot analysis were used to determine mRNA and protein expression levels, respectively. The results revealed that exposure to DB increased the expression levels of the transformation associated, protein 53, and cyclin-dependent kinase inhibitor $1 \mathrm{~A}$, and decreased the expression of cyclin-dependent kinase 2. The results of the present study demonstrated that DB can inhibit cell cycle progression and, therefore, offers potential as a beneficial antitumor drug.
\end{abstract}

\section{Introduction}

Plectranthus excisus and other tea-leaves of the Labiatae family are Isodons, which are widely distributed throughout northeast China. Diterpenoids, which are a typical component of Isodons, exhibit antitumor, antibacterial, anti-inflammatory and antioxidant effects, and provide cardiovascular protection (1-4). Diterpenoid B (DB) is synthesized by Plectranthus excisus. Previous studies have demonstrated that a number of Isodons contain extractable diterpenoids. In China, Isodon plants are currently used as raw materials to produce medicines,

Correspondence to: Professor Yang Li, Department of Pathophysiology, Key Laboratory of Pathobiology, Ministry of Education, College of Basic Medical Sciences, Jilin University, 126 Xinmin Street, Changchun, Jilin 130021, P.R. China

E-mail: lyang@jlu.edu.cn

${ }^{*}$ Contributed equally

Key words: cancer, cell cycle, p53 including tablet-based rubescens and anticancer drugs $(5,6)$. This present study aimed to provide a theoretical basis for the development of caudate lobe Isodon plants, and investigate whether DB is able to inhibit the proliferation and progression of melanoma. This was with the aim to establish a theoretical basis for the anti-tumor effect of traditional Chinese medicine.

\section{Materials and methods}

Reagents. The DB used in the present study was obtained from China-Japan Union Hospital chemical laboratory and 3-(4,5-dimethylthiazol-2-yl)-2,5-diphenyltetrazolium bromide (MTT) was purchased from Sigma-Aldrich (St. Louis, MO, USA). RPMI-1640 medium was purchased from Gibco Life Technologies (Carlsbad, CA, USA) and fetal bovine serum was purchased from HyClone Corp. (Logan, UT, USA). The following antibodies were purchased from Santa Cruz Biotechnology, Inc. (Dallas, TX, USA): Rabbit polyclonal cyclin-dependent kinase 2 (Cdk2; sc-163; 1:200), mouse monoclonal transformation related protein 53 (p53; sc-126; 1:200), rabbit polyclonal cyclin-dependent kinase inhibitor 1A (p21; sc-397; 1:200) and rabbit polyclonal checkpoint kinase 1 (Chk1; sc-7898; 1:200). Goat anti-mouse (sc-2005) and anti-rabbit (sc-2054) immunoglobulin $\mathrm{G}$ horseradish peroxidase-conjugated secondary antibodies were used (1:1,000; Santa Cruz Biotechnology, Inc.). The anti- $\beta$-actin antibody was purchased from Promega Corporation (Madison, WI, USA).

Cell culture. The B16 mouse melanoma cell line was maintained in RPMI-1640 medium, containing $10 \%$ fetal bovine serum, in an incubator with $5 \% \mathrm{CO}_{2}$ at $37^{\circ} \mathrm{C}$. Trypsin $(0.25 \%)$ was used to digest the cells.

MTT assay. B16 cells in the logarithmic growth phase were seeded into 96 -well plates at $\sim 5 \times 10^{4}$ cells $/ \mathrm{ml}$. Following incubation for $24 \mathrm{~h}$ at $37^{\circ} \mathrm{C}$, the cells were exposed to $0.5,1.0$, $2.0,4.0,8.0,16.0$ and $32.0 \mu \mathrm{g} / \mathrm{ml}$ of $\mathrm{DB}$ (the experimental groups) or remained untreated (control), with four wells for each group. The cells were further divided into 24 and $48 \mathrm{~h}$ treatment groups. Every $24 \mathrm{~h}$, MTT $(20 \mu \mathrm{l}$ of a $5 \mu \mathrm{g} / \mathrm{ml}$ solution) was added to the wells containing the cultured cells, which were then incubated for $4 \mathrm{~h}$. Following incubation at 
$37^{\circ} \mathrm{C}$, the culture medium was removed and $150 \mu \mathrm{l}$ dimethyl sulfoxide was added. The absorbance (A) was measured using a microplate reader (Bio-Rad 550; Bio-Rad Laboratories, Inc., Hercules, CA, USA) at $490 \mathrm{~nm}$, and the rate of the inhibition of cell growth was calculated using the following formula: Cell growth inhibition rate $(\%)=\left(1-\mathrm{A}_{\text {experimental group }} / \mathrm{A}_{\text {control }}\right.$ group) X 100 .

Analysis of cell morphology. B16 cells in the logarithmic growth phase were digested with trypsin and seeded into 96-well plates with $100 \mu \mathrm{l} /$ well suspension containing $\sim 5 \times 10^{4}$ cells $/ \mathrm{ml}$. Following culture for $24 \mathrm{~h}$, the media was discarded. The doses of DB and the incubation durations were as described for the MTT assay above. The morphology of the cells was observed using an inverted phase contrast microscope (BX41-PHD-P11; Olympus, Numazu-shi, Japan).

Reverse transcription-quantitative polymerase chain reaction (RT-qPCR). The mRNA expression was measured in the $\mathrm{B} 16$ cells in the logarithmic growth phase following treatment with DB $(0.5,1.0$ and $2.0 \mu \mathrm{g} / \mathrm{ml})$ for 24 or $48 \mathrm{~h}$. The cells were digested with $0.25 \%$ trypsin and pelleted by centrifugation at $2,000 \mathrm{x} \mathrm{g}$ for $5 \mathrm{~min}$ at $37^{\circ} \mathrm{C}$. The total RNA was extracted with TRIzol (Invitrogen Life Technologies, Carlsbad, CA, USA) and the concentration and purity of the RNA samples were determined by measuring the A260 and A280 optical density values using an ultraviolet (UV) spectrophotometer (UV-2401PC; Bayer AG, Leverkusen, Germany). The cDNA $(100 \mathrm{ng})$ was obtained by RT of $1 \mu \mathrm{g}$ mRNA with SMART ${ }^{\circledR}$ MMLV Reverse Transcriptase (639523; Takara Bio, Inc., Otsu, Japan). The PCR kit used was 2XEasyTaq PCR SuperMix (AS111-02; Beijing TransGen Biotech Co., Ltd., Beijing, China). The primer sequences, which were obtained from Sangon Biotech, Co., Ltd. (Shanghai, China), were as follows: p53, upstream 5'-CATGGACGATCTGTTGCTG-3' and downstream 5'-TCGGGTGGCTCATAAGGT-3'; p21, upstream 5'-AGCTCAATGGACTGGAAGGG-3' and downstream 5'-GAGCTGGAAGGTGTTTGGGG-3'; Cdk2, upstream 5'-GTTGACGGGAGAAGTTGTGG-3' and downstream 5'-GAAGGACACGGTGAGAATGG-3'; Chk1, upstream 5'-CTTTGGGAGAAGGTGCCTAT-3' and downstream 5'-ATGCCGAAATACCGTTGC-3'. $\beta$-actin was used as an internal control to assess the quality of the cDNA templates. The sequences of the $\beta$-actin primers were as follows: Upstream 5'-GTAAAGACCTCTATGCCAACACA-3' and downstream 5'-GGACTCATCGTACTCCTGCTTG-3'. The sizes of the amplified fragments for $\mathrm{p} 53, \mathrm{p} 21, \mathrm{Cdk} 2, \mathrm{Chk} 1$ and $\beta$-actin were 543, 485, 302, 431 and $226 \mathrm{bp}$, respectively. The conditions used for qPCR of the p53, p21, Cdk2, and Chk1 genes were as follows: $95^{\circ} \mathrm{C}$ for $5 \mathrm{~min} ; 30$ cycles of $94^{\circ} \mathrm{C}$ for $30 \mathrm{sec}, 55^{\circ} \mathrm{C}$ for $30 \mathrm{sec}, 72^{\circ} \mathrm{C}$ for $45 \mathrm{sec}$ and $72^{\circ} \mathrm{C}$ for $5 \mathrm{~min}$. The qPCR products were visualized using a camera and a digital gel imaging system (GIS; Tanon 2500R; Tanon Science \& Technology Co., Ltd., Shanghai, China). GIS was used to determine the grayscale values of the electrophoretic bands for p53, p21, Cdk2 and Chk1. The expression levels of these genes were expressed as a relative ratio of mRNA against the mRNA of $\beta$-actin.

Western blotting. Western blotting was used to determine the protein expression levels in the B16 cells in the logarithmic growth phase following exposure to $\mathrm{DB}(0.5,1.0$ or $2.0 \mu \mathrm{g} / \mathrm{ml})$ for 24 or $48 \mathrm{~h}$. Following treatment with DB, the cells were washed with phosphate-buffered saline (PBS) and centrifuged at $2,000 \times \mathrm{g}$ for $5 \mathrm{~min}$. Following centrifugation, protein homogenization buffer $(100 \mu \mathrm{l}), \beta$-mercaptoethanol $(1.2 \mu \mathrm{l})$ and $200 \mathrm{mmol} / \mathrm{l}$ phenylmethylsulfonyl fluoride $(0.3 \mu \mathrm{l})$ were added to the resuspended cells. The cells were ruptured using an ultrasonic homogenizer, and the protein concentrations were determined using a microplate reader. Protein $(40 \mu \mathrm{g})$ from each sample was electrophoresed and the proteins were transferred from the $12 \%$ SDS-PAGE gel (Beijing Solarbio Science \& Technology Co., Ltd., Shanghai, China) onto a polyvinylidene fluoride membrane (EMD Millipore, Billerica, MA, USA). The membranes were blocked with 5\% non-fat milk prior to being incubated at $4{ }^{\circ} \mathrm{C}$ overnight with antibodies directed against p53, p21, Cdk2 and Chk1. Following incubation with secondary antibodies for $1 \mathrm{~h}$ at room temperature, the membranes were processed and analyzed. The expression levels of p53, p21, Cdk2 and Chk1 were quantified using a color image analysis system (Tanon 4100; Tanon Science \& Technology Co., Ltd.).

Flow cytometry. The B16 cells were incubated with DB for 24 or 48 h, digested with EDTA (Sangon Biotech, Co., Ltd.), harvested and incubated in $70 \%$ ethanol at $4^{\circ} \mathrm{C}$ for $24 \mathrm{~h}$. A total of $\sim 1 \times 10^{6}$ cells were resuspended in $100 \mu 1$ PBS. Subsequently, $5 \mu \mathrm{l}$ propidium iodide (PI) was added and the cells were incubated in PI for $30 \mathrm{~min}$ at room temperature in the dark. The cell cycle status was then assessed using flow cytometry (FACSCalibur; BD Biosciences, San Jose, CA, USA).

Statistical analysis. The data are expressed as the mean \pm standard deviation. One-way analysis of variance was used to determine whether differences were present between the groups. All analyses were performed using SPSS 11.5 statistical software (SPSS, Inc., Chicago, IL, USA). P $<0.05$ was considered to indicate a statistically significant difference.

\section{Results}

Effects of DB treatment on the proliferation of B16 cells. The effects of different concentrations of DB on the B16 cells was determined by incubating the cells with DB for 24 or $48 \mathrm{~h}$. The results of this analysis are presented in Tables I and II, and Fig. 1. Following 24 or 48 h treatment with DB, proliferation was significantly more inhibited in the cells treated with $0.5 \mu \mathrm{g} / \mathrm{m}$, compared with the cells of the control groups ( $24 \mathrm{~h}, \mathrm{P}<0.05 ; 48 \mathrm{~h}, \mathrm{P}<0.01)$. Following $24 \mathrm{~h}$ exposure to $\mathrm{DB}$, the proliferation of the cells treated with $0.5,1.0$, $2.0,4.0,8.0,16.0$ and $32.0 \mu \mathrm{g} / \mathrm{ml}$ were inhibited by 11.06 , $24.95,39.23,63.28,68.90,78.54$ and $79.87 \%$, respectively (Table I). Following $48 \mathrm{~h}$ exposure to DB, the proliferation of cells treated with $0.5,1.0,2.0,4.0$ and $8.0 \mu \mathrm{g} / \mathrm{ml}$ groups were inhibited by $38.53,51.87,68.32,80.84$ and $86.11 \%$, respectively (Table II). These findings indicated that inhibition of the proliferation of B16 cells by DB is time- and dose-dependent (Tables I and II).

Effects of treatment with DB on the morphology of B16 cells. The B16 cells were incubated with different doses of DB, 
following which their morphology was assessed using an inverted phase contrast microscope. The results revealed that the adherent control cells grew well and were transparent, with good refractive indices and smooth, clear boundaries. In addition, proliferation of the control cells was robust. The effects of treatment with DB on cell morphology manifested slowly. A small number of cells became round and smaller in size following treatment with $1 \mu \mathrm{g} / \mathrm{ml} \mathrm{DB}$ for $24 \mathrm{~h}$, and a number of dead, floating cells were observed. Pronounced changes in cell morphology were increasingly apparent with increased doses of DB. Following treatment with $2 \mu \mathrm{g} / \mathrm{ml}$ DB for $48 \mathrm{~h}$, a marked increase in cell death was observed. The viable cells lost their shape and their surfaces were no longer smooth. Visible cell debris was also present (Fig. 1).

Effects of treatment with DB on the proliferation of B16 cells. The results of the analysis of the cell cycle using flow cytometry are shown in Fig. 2. The area in front of the red peak represents the G0-G1 phases, the area following the red square represents the $\mathrm{G} 2-\mathrm{M}$ phases and the blue diagonal peaks represent the $\mathrm{S}$ phase. No cell cycle arrest was observed in the cells in the blank control group during any phase of the cell cycle. However, the cells exposed to DB exhibited arrest, predominantly in the $\mathrm{G} 1$ phase. The number of B16 cells arrested in the G1 phase following exposure to $0.5,1.0$ or $2.0 \mu \mathrm{g} / \mathrm{ml} \mathrm{DB}$ for 24 or $48 \mathrm{~h}$ was dose-dependent (Fig. 2 and Table III).

Determination of the $m R N A$ expression levels of $p 53, p 21$, $C d k 2$, and Chk1 using RT-qPCR. The effects of treatment with $0.5,1.0$ or $2.0 \mu \mathrm{g} / \mathrm{ml} \mathrm{DB}$ on gene expression in the B16 cells was analyzed subsequent to 24 and $48 \mathrm{~h}$ exposure. Following treatment for $24 \mathrm{~h}$, the mRNA expression levels of p53, p21 and Chk1 were significantly increased in the cells treated with 1.0 or $2.0 \mu \mathrm{g} / \mathrm{ml} \mathrm{DB}$, compared with the control cells $(\mathrm{P}<0.05)$. Following $48 \mathrm{~h}$ exposure, the mRNA expression levels of p53 were significantly increased only in cells treated with $2.0 \mu \mathrm{g} / \mathrm{ml} \mathrm{DB}$, while the mRNA expression levels of p21 and Chk1 were significantly increased in cells treated with all three doses of $\mathrm{DB}(\mathrm{P}<0.05$; Fig. 3). By contrast, the mRNA expression levels of Cdk2 were significantly decreased in the cells treated with $2.0 \mu \mathrm{g} / \mathrm{ml} \mathrm{DB}$ for $24 \mathrm{~h}$ and in the cells treated with $1.0 \mu \mathrm{g} / \mathrm{ml}$ or $2.0 \mu \mathrm{g} / \mathrm{ml} \mathrm{DB}$ for $48 \mathrm{~h}(\mathrm{P}<0.05$; Fig. 3).

Determination of the protein expression levels of p53, p21, $C d k 2$ and Chk1 using western blot analysis. The effects of treatment with $0.5,1.0$ or $2.0 \mu \mathrm{g} / \mathrm{ml} \mathrm{DB}$ on the B16 cells were analyzed following 24 or $48 \mathrm{~h}$ exposure. The protein expression levels of p53,p21 and Chk1 were significantly increased in the cells treated with DB, compared with the control cells (All $\mathrm{P}<0.05)$, with the exception of Chk1 in the cells treated with $0.5 \mu \mathrm{g} / \mathrm{ml} \mathrm{DB}$ for $24 \mathrm{~h}$. The protein expression of $\mathrm{Cdk} 2$ in the cells treated with $2.0 \mu \mathrm{g} / \mathrm{ml} \mathrm{DB}$ for 24 or $48 \mathrm{~h}$ was decreased significantly, compared with that observed in the control cells (Fig. 4).

\section{Discussion}

Melanoma is a highly malignant, melanin-producing tumor. A study in the United States reported that during the past two
Table I. Inhibition of the proliferation of B16 cells following treatment with DB for $24 \mathrm{~h}$.

\begin{tabular}{lcc}
\hline DM $(\mu \mathrm{g} / \mathrm{ml})$ & OD value & $\begin{array}{c}\text { Inhibitory } \\
\text { rate }(\%)\end{array}$ \\
\hline 0 (control) & $0.637 \pm 0.038$ & 0 \\
0.5 & $0.567 \pm 0.042$ & $11.06^{\mathrm{a}}$ \\
1.0 & $0.478 \pm 0.013$ & $24.95^{\mathrm{b}}$ \\
2.0 & $0.387 \pm 0.047$ & $39.23^{\mathrm{b}}$ \\
4.0 & $0.234 \pm 0.037$ & $63.28^{\mathrm{b}}$ \\
8.0 & $0.198 \pm 0.027$ & $68.90^{\mathrm{b}}$ \\
16.0 & $0.137 \pm 0.011$ & $78.54^{\mathrm{b}}$ \\
32.0 & $0.128 \pm 0.012$ & $79.87^{\mathrm{b}}$ \\
\end{tabular}

OD values are expressed as the mean \pm standard deviation. ${ }^{\mathrm{a}} \mathrm{P}<0.05$, compared with the control group; ${ }^{\mathrm{b}} \mathrm{P}<0.01$, compared with the control group $(n=4)$. DB, diterpenoid B; OD, optical density.

Table II. Inhibition of the proliferation of B16 cells treated with DB for $48 \mathrm{~h}$.

\begin{tabular}{lcc}
\hline DM $(\mu \mathrm{g} / \mathrm{ml})$ & OD value & $\begin{array}{c}\text { Inhibitory } \\
\text { rate }(\%)\end{array}$ \\
\hline 0 (control) & $1.0245 \pm 0.100$ & 0 \\
0.5 & $0.630 \pm 0.051$ & $38.53^{\mathrm{a}}$ \\
1.0 & $0.493 \pm 0.021$ & $51.87^{\mathrm{a}}$ \\
2.0 & $0.325 \pm 0.010$ & $68.32^{\mathrm{a}}$ \\
4.0 & $0.196 \pm 0.021$ & $80.84^{\mathrm{a}}$ \\
8.0 & $0.142 \pm 0.004$ & $86.11^{\mathrm{a}}$ \\
16.0 & $0.140 \pm 0.019$ & $86.35^{\mathrm{a}}$ \\
32.0 & $0.137 \pm 0.010$ & $86.60^{\mathrm{a}}$ \\
\hline
\end{tabular}

OD values are presented as the mean \pm standard deviation. ${ }^{\mathrm{a}} \mathrm{P}<0.01$, vs . control $(\mathrm{n}=4)$. DB, diterpenoid B; OD, optical density.

Table III. Analysis of the cell cycle distribution of the cells treated with DB for 24 or $48 \mathrm{~h}$, assessed using flow cytometry.

\begin{tabular}{llll}
\hline $\mathrm{DM}(\mu \mathrm{g} / \mathrm{ml})$ & $\mathrm{G} 1$ phase $(\%)$ & $\mathrm{G} 2$ phase $(\%)$ & $\mathrm{S}$ phase $(\%)$ \\
\hline $24 \mathrm{~h}$ & & & \\
0 (control) & $48.34 \pm 1.05$ & $3.81 \pm 0.90$ & $48.40 \pm 0.57$ \\
0.5 & $57.54 \pm 1.71^{\mathrm{a}}$ & $1.78 \pm 0.60^{\mathrm{a}}$ & $41.73 \pm 1.06^{\mathrm{a}}$ \\
1.0 & $62.57 \pm 1.21^{\mathrm{a}}$ & $0.94 \pm 0.08^{\mathrm{a}}$ & $36.49 \pm 1.24^{\mathrm{a}}$ \\
2.0 & $73.45 \pm 1.09^{\mathrm{a}}$ & $1.00 \pm 0.54^{\mathrm{a}}$ & $25.66 \pm 1.35^{\mathrm{a}}$ \\
$48 \mathrm{~h}$ & & & \\
$0($ control $)$ & $45.39 \pm 2.64$ & $4.57 \pm 0.45$ & $45.95 \pm 0.48$ \\
0.5 & $57.40 \pm 0.87^{\mathrm{a}}$ & $1.62 \pm 0.37^{\mathrm{a}}$ & $43.06 \pm 0.94^{\mathrm{a}}$ \\
1.0 & $61.44 \pm 1.07^{\mathrm{a}}$ & $1.09 \pm 0.21^{\mathrm{a}}$ & $39.30 \pm 0.74^{\mathrm{a}}$ \\
2.0 & $64.30 \pm 0.72^{\mathrm{a}}$ & $0.47 \pm 0.23^{\mathrm{a}}$ & $36.46 \pm 1.12^{\mathrm{a}}$ \\
\hline
\end{tabular}

The data are expressed as the mean \pm standard deviation. ${ }^{\mathrm{a}} \mathrm{P}<0.05$, compared with the control group $(n=3)$. DB, diterpenoid $B$. 


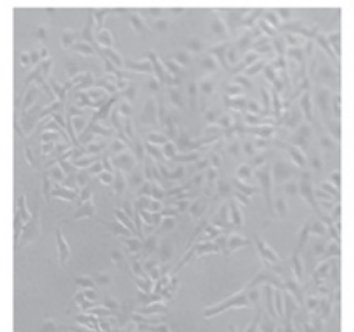

24 h control

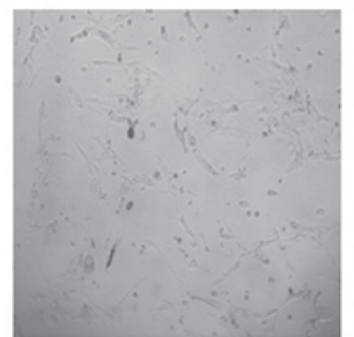

$24 \mathrm{~h} 1.0 \mu \mathrm{g} / \mathrm{ml}$

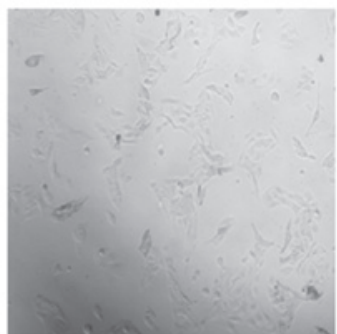

$24 \mathrm{~h} 0.5 \mu \mathrm{g} / \mathrm{ml}$

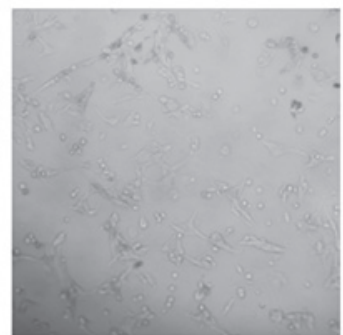

$24 \mathrm{~h} 2.0 \mu \mathrm{g} / \mathrm{ml}$

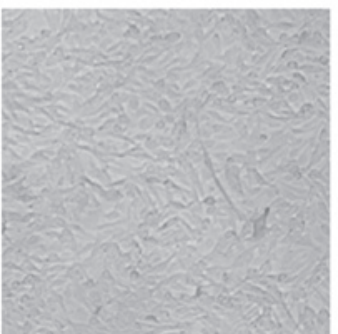

$48 \mathrm{~h}$ control

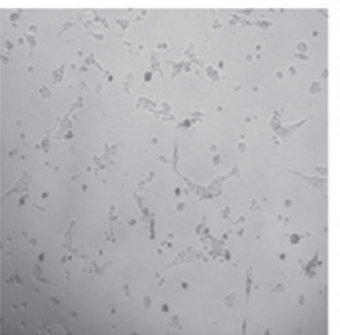

$48 \mathrm{~h} 1.0 \mu \mathrm{g} / \mathrm{ml}$

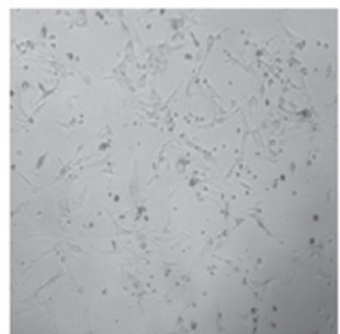

$48 \mathrm{~h} 0.5 \mu \mathrm{g} / \mathrm{ml}$

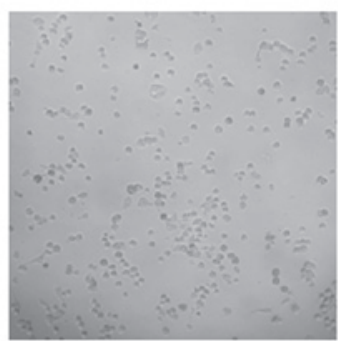

$48 \mathrm{~h} 2.0 \mu \mathrm{g} / \mathrm{ml}$

Figure 1. Diterpenoid B causes morphological changes in B16 cells following 24 or 48 h of exposure (magnification, x100). With diterpenoid B, the cells turned round and did not attach, and many fragments were observed in the medium. The morphological alterations were more significant with increases in dose and duration of treatment.

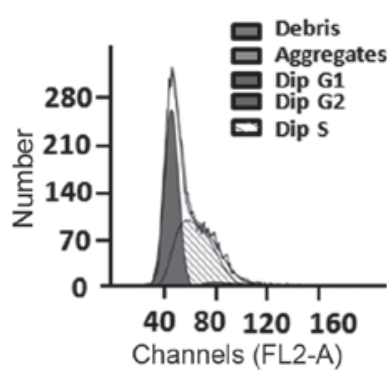

24 h control

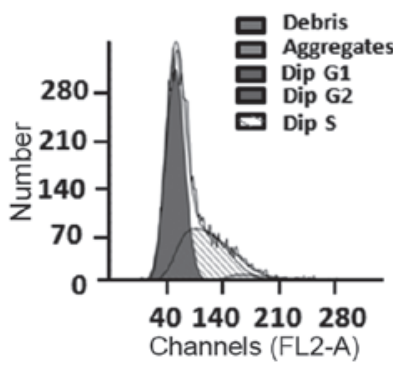

$24 \mathrm{~h} 1.0 \mu \mathrm{g} / \mathrm{ml}$

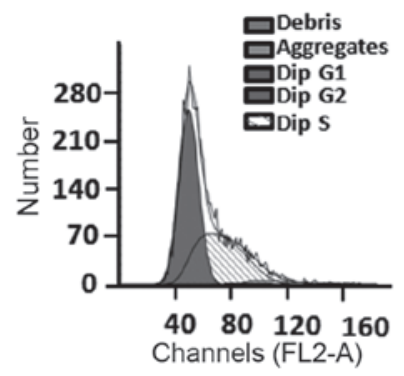

$24 \mathrm{~h} 0.5 \mu \mathrm{g} / \mathrm{ml}$

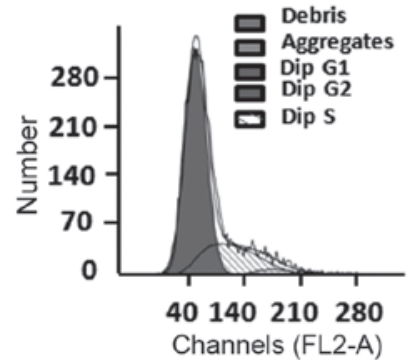

$24 \mathrm{~h} 2.0 \mu \mathrm{g} / \mathrm{ml}$

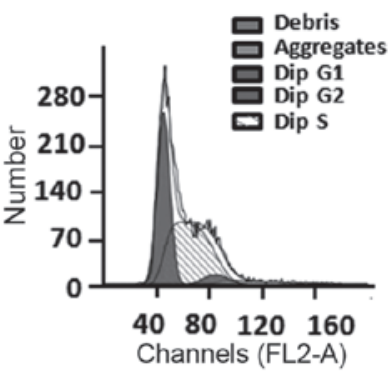

$48 \mathrm{~h}$ control

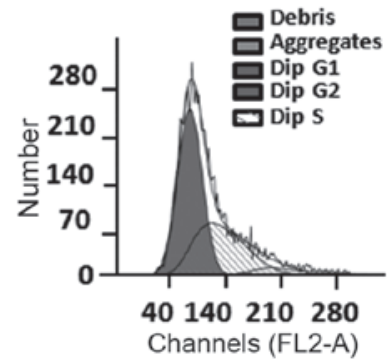

$48 \mathrm{~h} 1.0 \mu \mathrm{g} / \mathrm{ml}$

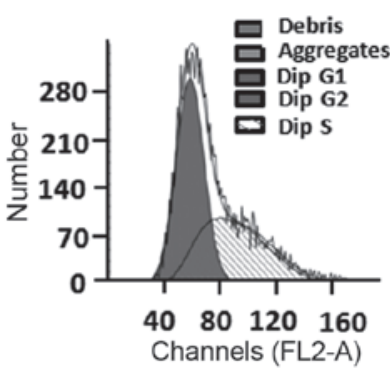

$48 \mathrm{~h} 0.5 \mu \mathrm{g} / \mathrm{ml}$

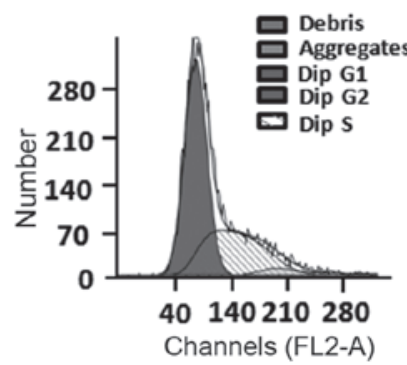

$48 \mathrm{~h} 2.0 \mu \mathrm{g} / \mathrm{ml}$

Figure 2. Flow cytometric analysis of the effects of treatment with diterpenoid B on the cell cycle progression of B16 cells.

decades, the incidence of melanoma has increased annually, and of the 76,250 patients with newly diagnosed melanoma, 9,180 succumbed to mortality (7).

A predilection for left-sided skin cancer in the United States is considered to be associated with exposure to UV light whilst driving (8). The disease has a poor prognosis and mortality rates due to skin cancer account for $>50 \%$ of the total mortality (9). Therefore, identifying novel treatments is essential.

The root cause of tumor formation is cell cycle disorder, caused by unrestricted cell proliferation, and cell cycle-associated genes are important in this process. Cdk2 is a cyclin-dependent kinase, which binds to the regulatory proteins Cyclin E and Cyclin A. Activation of the Cyclin E-Cdk2 complex promotes the progression of the cell cycle through the G1/S phase restriction point into the $\mathrm{S}$ phase of the cell cycle. Following entry into the $\mathrm{S}$ phase, $\mathrm{Cdk} 2$ forms a complex with Cyclin A to regulate DNA and centrosome replication, and remaining at the G2/M phase checkpoint during the conversion process may promote the occurrence of mitosis (10-12).

p53 is an important regulator of the cell cycle. In mammalian cells, wild-type p53 is important in the G1/S phase transition (13) by binding to and activating the regulatory region 

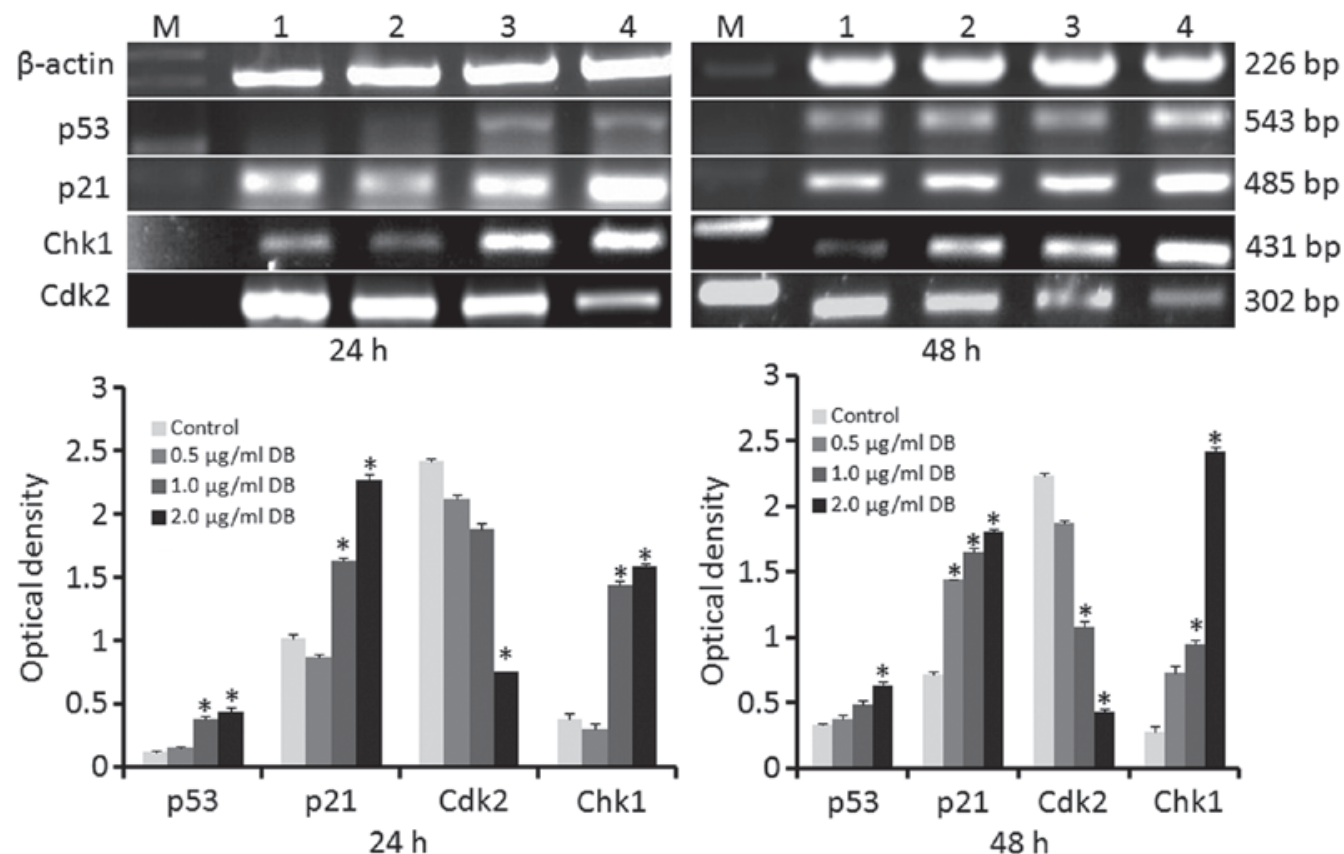

Figure 3. Reverse transcription-quantitative polymerase chain reaction analysis of the mRNA expression levels of $p 53, p 21, C h k 1$ and $C d k 2$ in B16 cells following treatment with DB for 24 or $48 \mathrm{~h}$. Lane 1, control group; lane 2, $0.5 \mu \mathrm{g} / \mathrm{ml} ;$ lane 3, $1.0 \mu \mathrm{g} / \mathrm{ml} ;$ lane $4,2.0 \mu \mathrm{g} / \mathrm{ml}$ DB group. The data are expressed as the mean \pm standard deviation. $\mathrm{P}<0.05$, compared with the control group. $\mathrm{DB}$, diterpenoid $\mathrm{B} ; \mathrm{M}$, marker.
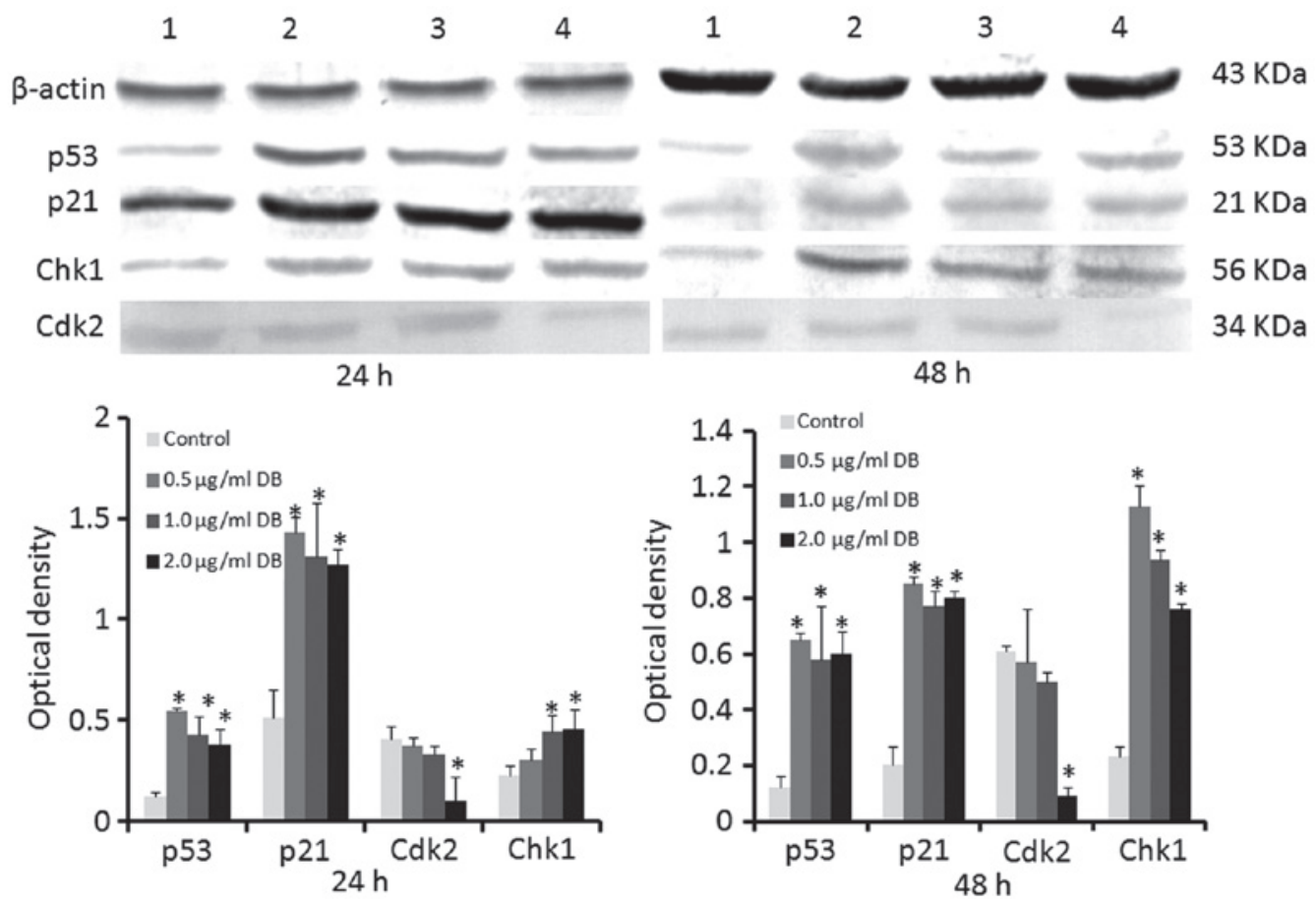

Figure 4. Western blot analysis of the protein expression levels of p53, p21, Chk1 and Cdk2 in B16 cells following treatment with DB for 24 or $48 \mathrm{~h}$. Lane 1 , control group; lane $2,0.5 \mu \mathrm{g} / \mathrm{ml}$; lane $3,1.0 \mu \mathrm{g} / \mathrm{ml}$; lane $4,2.0 \mu \mathrm{g} / \mathrm{ml} \mathrm{DB}$ group. The data are expressed as the mean \pm standard deviation. ${ }^{*} \mathrm{P}<0.05$, compared with the control group. DB, diterpenoid B.

of p21. The formation of p53-p21 complexes prevents the cells from progressing between the G1 phase and the S phase. In addition, the activation of p21 inhibits the activity of Cdks. This inhibition arrests the cell cycle at the G0/G1 phase transition and inhibits proliferation.

Chk1 is a DNA damage-induced cell cycle checkpoint mediator, which is important in the G2 phase. The activation of Chk1 via phosphorylation, by cell division cycle 25C, arrests cells at the G2/M phase transition (14-16). Previous studies have demonstrated that G2-phase arrest ensures the integrity and stability of chromosomes, and prevents cells with abnormal chromosomes from undergoing mitosis (17-19). Accordingly, tumor cells with functional Chk1 remain in the G2 phase and fail to divide. 
In conclusion, the present study demonstrated that caudate Isodon DB, synthesized by Plectranthus excisus, inhibited the proliferation of B16 cells. Treatment with DB increased the mRNA and protein expression levels of p53, p21 and Chk1, and decreased the mRNA and protein expression levels of Cdk2. These findings indicated that DB affected the proliferation in B16 cells by activating the expression levels of p53 and p21. Increasing the expression levels of these two genes inhibited the activity of $\mathrm{Cdk} 2$ and arrested the cells in the $\mathrm{G} 1$ phase. $\mathrm{Cdk} 2$ is also regulated by Chk1 at the G2/M phase transition (20). This regulation maintains the cells in the $\mathrm{G} 2$ phase and prevents them from dividing. Therefore, the results of the present study demonstrated that DB can inhibit cell cycle progression and, thus offer potential as a beneficial antitumor drug.

\section{Acknowledgements}

This study was supported by the Research Fund for the Scientific and Technological Development Plan Project in Jilin Province (grant. no. 20120727), the National Natural Science Foundation of China (grant. no. 81000271), the Natural Science Foundation of Jilin Province (grant. no. 201115115) and the “ $12^{\text {th }}$ Five-Year-Program" Science and Technology Research Plan of the Ministry of Education of Jilin Province.

\section{References}

1. Li D, Wu LJ, Tashiro SI, Onodera $\mathrm{S}$ and Ikejima $\mathrm{T}$ Oridonin-induced A431 cell apoptosis partially through blockage of the Ras/Raf/ERK signal pathway. J Pharmacol Sci 103: 56-66, 2007.

2. Huang J, Wu L, Tashiro S, Onodera S and Ikejima T: A comparison of the signal pathways between the TNF alpha- and oridonin-induced murine L929 fibrosarcoma cell death. Acta Med Okayama 59: 261-270, 2005.

3. Bai NS, He K,Zhou Z, et al: Flavonoids from Rabdosia rubescens exert anti-inflammatory and growth inhibitory effect against human leukemia HL-60 cells. Food Chem 122: 831-835, 2010.

4. Gui MY, Aoyagi Y, Jin YR, Li XW, Hasuda T and Takeya K: Excisanin $\mathrm{H}$, a novel cytotoxic 14,20-epoxy-ent-kaurene diterpenoid and three new ent-kaurene diterpenoids from Rabdosia excisa. J Nat Prod 67: 373-376, 2004.
5. Huang ZY, Huang B, Xiao CJ, Dong X and Jiang B: Two new labdane diterpenoids from the rhizomes of Isodon yuennanensis. Nat Prod Res 29:628-632, 2015.

6. Wu HY, Wang WG, Jiang HY, Du X, Li XN, Pu JX and Sun HD: Cytotoxic and anti-inflammatory ent-kaurane diterpenoids from Isodon wikstroemioides. Fitoterapia 98: 192-198, 2014.

7. Siegel R, Naishadham D and Jemal A: Cancer statistics, 2013. Ca-Cancer J Clin 63: 11-30, 2013.

8. Dores GM, Huycke MM and Devesa SS: Melanoma of the skin and laterality. J Am Acad Dermatol 64: 193-195, 2011.

9. Ahmed I: Malignant melanoma: Prognostic indicators. Mayo Clin Proc 72: 356-361, 1997.

10. Minhajat R, Mori D, Yamasaki F, Sugita Y, Satoh T and Tokunaga O: Endoglin (CD105) expression in angiogenesis of colon cancer: Analysis using tissue microarrays and comparison with other endothelial markers. Virchows Arch 448: 127-134, 2006.

11. Uneda S, Toi H, Tsujie T, Tsujie M, Harada N, Tsai $H$ and Seon BK: Anti-endoglin monoclonal antibodies are effective for suppressing metastasis and the primary tumors by targeting tumor vasculature. Int J Cancer 125: 1446-1453, 2009.

12. Lee SY, Hong YD, Felipe PM, Pyun MS and Choi SJ: Radiolabeling of monoclonal anti-CD105 with (177) Lu for potential use in radioimmunotherapy. Appl Radiat Isot 67: 1366-1369, 2009.

13. Ozaki T and Nakagawara A: Role of $\mathrm{p} 53$ in cell death and human cancers. Cancers (Basel) 3: 994-1013, 2011.

14. Bartek J and Lukas J: Chk1 and Chk2 kinases in checkpoint control and cancer. Cancer cell 3: 421-429, 2003.

15. Senderowicz AM: Novel direct and indirect cyclin-dependent kinase modulators for the prevention and treatment of human neoplasms. Cancer Chemother Pharmacol 52: S61-S73, 2003.

16. Chen Y and Sanchez Y: Chk1 in the DNA damage response: conserved roles from yeasts to mammals. DNA Repair 3: 1025-1032, 2004.

17. Pawlik TM and Keyomarsi K: Role of cell cycle in mediating sensitivity to radiotherapy. Int J Radiat Oncol Biol Phys 59: 928-942, 2004

18. Carpi S, Fogli S, Romanini A, Pellegrino M, Adinolfi B, Podestà A, Costa B, Da Pozzo E, Martini C, Breschi MC and Nieri P: AM251 induces apoptosis and G2/M cell cycle arrest in A375 human melanoma cells. Anticancer Drugs: May 12, 2015 (Epub ahead of print).

19. Peng ZG, Yao YB, Yang J, Tang YL and Huang X: Mangiferin induces cell cycle arrest at G2/M phase through ATR-Chk1 pathway in HL-60 leukemia cells. Genet Mol Res 14: 4989-5002, 2015.

20. Qi W, Xie C, Li C, Caldwell JT, Edwards H, Taub JW, Wang Y, Lin $\mathrm{H}$ and Ge Y: CHK1 plays a critical role in the anti-leukemic activity of the weel inhibitor MK-1775 in acute myeloid leukemia cells. J Hematol Oncol 7: 53, 2014. 